\title{
Effects of Drying Conditions on the Antioxidant Activities and Volatile Compounds of Chrysanthemi Flos Flowers
}

\author{
Sung-Mun Bae ${ }^{1,2}$, Ae-Sil Na ${ }^{3}$, Hye-Kyeong Seo ${ }^{1}$, and Seung-Cheol Lee ${ }^{1 \dagger}$ \\ ${ }^{1}$ Department of Food Science and Biotechnology, Kyungnam University, Masan 631-701, Korea \\ ${ }^{2}$ Gyeongnam Agricultural Research and Extension Services, Jinju 660-370, Korea \\ ${ }^{3}$ Department of Biochemistry and Health Science, Changwon National University, Changwon 641-773, Korea
}

\begin{abstract}
The effects of drying conditions on the antioxidant activities, luteolin, and volatile compounds of Chrysanthemi Flos flowers were evaluated. The flowers were dried with hot-air or far-infrared radiation at $40^{\circ} \mathrm{C}, 50^{\circ} \mathrm{C}$ and $60^{\circ} \mathrm{C}$, respectively, to reach $22 \pm 1 \%$ of moisture content. Each $10 \mathrm{~g}$ of the dried flowers were extracted with $100 \mathrm{~mL}$ of $95 \%$ ethanol. Increasing temperature in hot-air dried (HAD) conditions increased the antioxidant activities of the flower extracts. However, increasing temperature in far-infrared dried (FID) conditions decreased the antioxidant activities of the extracts. Luteolin, one of main flavonoids of Chrysanthemi Flos flowers, was present in the highest content at $60^{\circ} \mathrm{C}$ FID flowers with a value of $139 \mu \mathrm{g} / \mathrm{mL}$. Thirteen volatile compounds including camphor and $\beta$-caryophyllene were identified in chromatograms. Higher amount of the volatiles were found at $50^{\circ} \mathrm{C}$ HAD and $40^{\circ} \mathrm{C}$ FID. The results indicated that the antioxidant activities and volatile compounds of Chrysanthemi Flos flowers were significantly affected by drying conditions.
\end{abstract}

Key words: antioxidant, Chrysanthemi Flos flowers, drying condition, volatile compounds

\section{INTRODUCTION}

Chrysanthemum (Chrysanthemum indicum L.) grows naturally in Korea, China and Japan. It is also called as Gamgug (sweet chrysanthemum) in Korea because of its sweet taste. In oriental traditional medicine, its flowers have been used to treat vertigo, hypertensive symptoms, and several infectious diseases such as pneumonia, colitis and stomatitis (1). Recent reports have demonstrated the medicinal action of chrysanthemum including anti-inflammatory, immunomodulatory, anti-bacteria and anti-oxidant activities (2,3). Chrysanthemum contain a variety of flavonoid compounds, essential oils, phenolics, lactones, and sesquiterpenes (4-7). Four kinds of flavonoids, luteolin, apigenin, apigenin 7-O- $\beta$-D-glucose, and luteolin 7-O- $\beta$-D-glucose, have been identified in this plant (8). Also, one of flavonoids, sesquiterpene lactones containing cumambrin A, cumambrin B, arteglasin A, and angeloyljadin, were found in chrysanthemums (4,9-11). Luteolin has been reported to have significant medicinal effects of antispasmodic, anti-inflammatory and anti-tumor activities (12-15). Various volatile constituents in essential oils of chrysanthemum are also reported to exhibit antimicrobial or anticancer activities (16-20).

Previously, crude oriental medicines were mostly pre- pared in a natural drying way, with the use of shade, wind or sunlight, but now they are usually dried with drying equipment that uses heat or air. Despite the development of the drying equipment, there have been very few studies of the effect of drying conditions on the quality properties of each crude drug. The dried Chrysanthemi Flos flowers are generally traded on the basis of external appearance, such as color and smell. In this study, we evaluated the effect of drying conditions on antioxidant activities and volatile compounds in the Chrysanthemi Flos flowers. Furthermore, luteolin levels were also analyzed under different drying conditions. Luteolin is one of the key bioactive compounds of the Chrysanthemi Flos flower.

\section{METERIALS AND METHODS}

Chemicals and plant materials

Fresh Chrysanthemi Flos flowers were collected from the Gyeongnam Agricultural Research and Extension Services of the Republic of Korea. Luteolin, 1,1-dinitrophenyl-2-picrylhydrazyl (DPPH) and 2,2'-azino-bis (3-ethylbenzthiazoline-6-sulfonic acid) (ABTS) tablets were purchased from Sigma Chemical Co. (St. Louis, MO, USA), superoxide dismutase (SOD) assay kit from Dojindo Molecular Technologies, Inc. (Gaithersburg,

${ }^{\dagger}$ Corresponding author. E-mail: sclee@kyungnam.ac.kr

Phone: +82-55-249-2684, Fax: +82-55-249-2995 
MD, USA), and Folin-Ciocalteu reagent from Wako Pure Chemical Industries, Ltd. (Osaka, Japan). All the other chemical reagents used were analytical grade. The water used for sample preparation and HPLC was purified with a Super Purity Water System (Purite Ltd., Oxon, England) with a resistivity of $17.5 \mathrm{M} \Omega$ and above.

\section{Drying conditions and preparation of extracts}

The Chrysanthemi Flos flowers (500 g) were dried with hot-air $\left(170 \mathrm{~m}^{3} / \mathrm{min}\right.$ ) dryer (inner volume $6.5 \mathrm{~m}^{3}$, HSED-1.5, Hansung Industrial Co., Iksan, Korea) or far-infrared dryer with a far-infrared heater (output 300 W, Hakko Electric Machine Works Co., Nagoya, Japan) at $40^{\circ} \mathrm{C}, 50^{\circ} \mathrm{C}$, and $60^{\circ} \mathrm{C}$, respectively to reach $22 \pm 1 \%$ of moisture content, which is the most common drying condition. Moisture contents were checked by comparing with thoroughly dried flowers. Extraction was performed by soaking the Chrysanthemi Flos flowers (10 g dried weight) in $100 \mathrm{~mL}$ of $95 \%$ ethanol in a shaking incubator $(100 \mathrm{rpm})$ for $24 \mathrm{hr}$ at $25^{\circ} \mathrm{C}$. After filtration through a Whatman No.3 filter paper (Advantec Co., Tokyo, Japan), the solvent (ethanol) was removed by evaporation to dryness under a reduced pressure. The extracts from flowers were then dissolved in $95 \%$ ethanol in a concentration of $300 \mu \mathrm{g} / \mathrm{mL}$ for experiments except for SOD activity determination, where the concentration was $100 \mu \mathrm{g} / \mathrm{mL}$.

\section{DPPH radical scavenging activity (RSA)}

The DPPH RSA of the flower extracts was measured by the method of Lee et al. (21). $0.2 \mathrm{~mL}$ of extracts were mixed with $1 \mathrm{~mL}$ of $0.041 \mathrm{mM}$ DPPH in ethanol for $10 \mathrm{~min}$, and then the optical density (OD) of the mixture was measured at a wavelength of $517 \mathrm{~nm}$ by a spectrophotometer. The DPPH RSA was calculated from the following equation:

$$
\% \text { DPPH RSA }=\frac{\text { Control OD }- \text { Sample OD }}{\text { Control OD }} \times 100
$$

\section{Superoxide dismutase (SOD) activity}

SOD activity was determined using SOD Assay Kit-WST. The kit consisted of four materials: water-soluble tetrazolium salts (WST) solution, enzyme solution, buffer solution, and dilution buffer. A $20 \mu \mathrm{L}$ sample solution was added to each sample well and blank 2 in a 96-well plate, and $20 \mu \mathrm{L}$ of double distilled water was added to blank 1 and blank 3 wells. $200 \mu \mathrm{L}$ of dilution buffer was added to blank 2 and blank 3 wells. A $20 \mu \mathrm{L}$ of WST working solution was added to each sample and blank 1, and mixed thoroughly. The reaction mixture was incubated at $37^{\circ} \mathrm{C}$ for $20 \mathrm{~min}$ and the optical density (OD) was measured at $450 \mathrm{~nm}$ by a microplate reader (Bio-Tek Instruments MQX200 $\mu$ Quant, Winooski,
VT). The SOD activity was calculated from the following equation:

$\%$ SOD activity $=[\{($ Blank 1 OD - Blank 3 OD $)-($ Sample OD - Blank2 OD) $\} /($ Blank1 OD - Blank3 OD) $] \times 100$

\section{ABTS radical scavenging activity (RSA)}

The hydrogen peroxide scavenging activity was determined by an ABTS-peroxidase medium according to the method of Muller (22). One $\mathrm{mL}$ of the extracts, 0.1 $\mathrm{mL}$ of $0.1 \mathrm{M}$ potassium phosphate buffer ( $\mathrm{pH}$ 5.0) and $20 \mu \mathrm{L}$ of $10 \mathrm{mM}$ hydrogen peroxide were mixed, and then incubated at $37^{\circ} \mathrm{C}$ for $5 \mathrm{~min}$. After the incubation, $30 \mu \mathrm{L}$ of $1.25 \mathrm{mM}$ ABTS (pH 5.0) in $0.05 \mathrm{M}$ phosphate buffer and $30 \mu \mathrm{L}$ of peroxidase $(1 \mathrm{U} / \mathrm{mL})$ were added to the mixture, and incubated at $37^{\circ} \mathrm{C}$ for $10 \mathrm{~min}$. The absorbance was read with an ELISA reader (Sunrise RC/TS/TS Color-TC/TW/BC/6Filter, Tecan Austria $\mathrm{GmbH}$, Grödig, Austria) at $405 \mathrm{~nm}$. The ABRT RSA was calculated from the following equation:

$\%$ ABTS RSA $=[1-($ Sample OD/Blank OD $)] \times 100$

\section{Total phenolic content (TPC)}

Total phenol contents (TPC) were determined by the method of Gutfinger (23). One $\mathrm{mL}$ of the extract was mixed with $1.0 \mathrm{~mL}$ of $2 \% \mathrm{Na}_{2} \mathrm{CO}_{3}$, followed by standing for $3 \mathrm{~min}$. The mixture was mixed with $0.2 \mathrm{~mL}$ of $50 \%$ Folin-Ciocalteu reagent, and after standing for $30 \mathrm{~min}$, centrifuged at 12,000 rpm for $5 \mathrm{~min}$ at room temperature. The absorbance was measured with a spectrophotometer (Shimadzu UV-1601, Tokyo, Japan) at $750 \mathrm{~nm}$ and gallic acid standard curve was obtained for the calibration of TPC. TPC were expressed as gallic acid equivalents (GAE).

\section{Analysis of luteolin}

Extraction was performed by soaking the Chrysanthemi Flos flowers ( $3 \mathrm{~g}$ dried weight) in $50 \mathrm{~mL}$ of $95 \%$ methanol in a shaking incubator $(100 \mathrm{rpm})$ for $24 \mathrm{hr}$ at $25^{\circ} \mathrm{C}$. After filtration through a Whatman No.3 filter paper (Advantec, Tokyo, Japan), the solvent (methanol) was removed by evaporation under a reduced pressure to dryness. The methanol extracts were fractionized to ethyl acetate and water. Ethyl acetate fractions were then collected and evaporated under reduced pressure to dryness. Finally, the dried ethyl acetate fractions were suspended in $20 \mathrm{~mL}$ of methanol (HPLC grade) and used for analysis. Luteolin was analyzed with HPLC (Shimadzu Co. Ltd., LC 20A, Kyoto, Japan) and Nova Pak C18 column $(3.9 \times 150 \mathrm{~mm})$ (Waters Co., Milford, MA) in condition of UV $365 \mathrm{~nm}$ and the injection volume was $10 \mu \mathrm{L}$. The composition of mobile phase was $\mathrm{MeOH}-$ $\mathrm{H}_{2} \mathrm{O}$-acetic acid (30:70:5, v/v/v) and the flow rate was $1.0 \mathrm{~mL} / \mathrm{min}$. 


\section{Analysis of volatile compounds}

The dried flowers were powdered with a homogenizer (MC-811C, Novita, Seoul, Korea). And $50 \mathrm{mg}$ of the powdered samples was then put into a $4-\mathrm{mL}$ vial and sealed with a top-hole cap and silicone rubber septa for solid-phase micro-extraction (SPME) sampling. The vial was thermostatically heated in $60^{\circ} \mathrm{C}$ heat block. The SPME needle with $100-\mu \mathrm{m}$ polydimethylsiloxane (PDMS) fiber was pushed through the septa. The fiber of SPME needle was extended into the headspace of the heated vial for $30 \mathrm{~min}$ and then withdrawn and removed from the vial. The needle was inserted immediately into the injection inlet of $\mathrm{GC}$ or $\mathrm{GC} / \mathrm{MS}$ for $5 \mathrm{~min}$. The gas chromatography (GC) used in the analysis of volatile compounds was Hewlett Packard 6890, equipped with a flame ionization detector coupled to Hewlett Packard Innowax $(50 \mathrm{~m} \times 0.20 \mathrm{~mm} \times 0.4 \mu \mathrm{m})$ column and the flow rate of $\mathrm{N}_{2}$ carrier gas was $0.5 \mathrm{~mL} / \mathrm{min}$. The column temperature increased from $70^{\circ} \mathrm{C}$ to $250^{\circ} \mathrm{C}$ at $3{ }^{\circ} \mathrm{C} / \mathrm{min}$. The gas chromatography-mass spectrometry (GS-MS) for the identification of volatile compounds was Shimadzu GC/MS-QP 2010 and the analysis was performed in the same method as the gas chromatography. The mass spectral identification was obtained from the WILEY library 7 (Scientific Instrument Services, Inc., Ringoes, NJ).

\section{Statistical analysis}

All the measurements were triplicated, and the mean values of each treatment were compared using one-way analysis of variance (ANOVA) followed by Duncan's multiple range test. $\mathrm{P}$ value of less than 0.01 was considered significant.

\section{RESULTS AND DISCUSSION}

\section{Drying time}

The time of drying to reach $22 \pm 1 \%$ of moisture con- tents in the Chrysanthemi Flos flower was 14 to 105 hr (Table 1). An increase in temperature resulted in a rapid decrease in the drying time. For example, the dry time at $40^{\circ} \mathrm{C}$ was $84 \mathrm{hr}$ for $\mathrm{HAD}$ method and $105 \mathrm{hr}$ for FID method, while at $60^{\circ} \mathrm{C}$ was $14 \mathrm{hr}$ and $19 \mathrm{hr}$, respectively. The HAD using heat and air flow was a more effective way to dry than by FID.

\section{Antioxidant activity}

A series of studies have demonstrated that the water extract from chrysanthemum had a strong anti-oxidation effect (2) and the methanol extract acted as an inhibitor of xanthine oxidase (24). Some flavonoids such as luteolin, apigenin, and acacetin 7-O-galactopyranose, a strong antioxidant polyphenol, were also found to be abundant in chrysanthemum $(10,11)$. For that reason, we studied the effect of drying conditions on the antioxidant activities of the Chrysanthemi Flos flowers.

All the antioxidant activities of the flower extracts from Chrysanthemi Flos were highly detected with increasing temperature in HAD condition (Table 2). DPPH RSA, ABTS RSA, and SOD activity of the extract at $40^{\circ} \mathrm{C}$ HAD condition were $36 \%, 31 \%$, and $82 \%$, respectively, while those at $60^{\circ} \mathrm{C}$ were $92 \%, 80 \%$, and

Table 1. The drying time for hot-air drying (HAD) or far-infrared drying (FID) in Chrysanthemi Flos flowers ${ }^{1)}$

\begin{tabular}{cccc}
\hline Drying conditions & $\begin{array}{c}\text { Drying time } \\
(\mathrm{hr})\end{array}$ & $\begin{array}{c}\text { Moisture content } \\
(\%)\end{array}$ \\
\hline \multirow{4}{*}{$\mathrm{HAD}$} & $40^{\circ} \mathrm{C}$ & 84 & 22 \\
& $50^{\circ} \mathrm{C}$ & 26 & 22 \\
& $60^{\circ} \mathrm{C}$ & 14 & 21 \\
\hline \multirow{4}{*}{$\mathrm{FID}$} & $40^{\circ} \mathrm{C}$ & 105 & 22 \\
& $50^{\circ} \mathrm{C}$ & 29 & 23 \\
& $60^{\circ} \mathrm{C}$ & 19 & 23 \\
\hline
\end{tabular}

${ }^{1)}$ Drying time was measured when moisture content of the flowers was reached to $22 \pm 1 \%$.

Table 2. Effect of hot-air drying (HAD) or far-infrared drying (FID) on antioxidant activities of the Chrysanthemi Flos flower extracts

\begin{tabular}{cccccc}
\hline \multirow{2}{*}{ Drying conditions } & \multicolumn{5}{c}{ Antioxidant activities ${ }^{1)}$} \\
\cline { 3 - 6 } & \multirow{2}{*}{$\mathrm{*}$ HAD } & DPPH-RSA (\%) & SOD Activity (\%) & ABTS-RSA (\%) & TPC $(\mu \mathrm{M})$ \\
\hline \multirow{2}{*}{ FID } & $40^{\circ} \mathrm{C}$ & $36.0 \pm 1.69^{2) \mathrm{c} 3)}$ & $81.9 \pm 3.49^{\mathrm{a}}$ & $31.4 \pm 1.02^{\mathrm{c}}$ & $202 \pm 1.10^{\mathrm{c}}$ \\
& $50^{\circ} \mathrm{C}$ & $91.4 \pm 0.97^{\mathrm{a}}$ & $80.7 \pm 3.71^{\mathrm{a}}$ & $62.4 \pm 1.40^{\mathrm{b}}$ & $200 \pm 1.10^{\mathrm{c}}$ \\
& $60^{\circ} \mathrm{C}$ & $92.0 \pm 0.55^{\mathrm{a}}$ & $85.0 \pm 0.39^{\mathrm{a}}$ & $80.1 \pm 12.42^{\mathrm{a}}$ & $234 \pm 1.39^{\mathrm{a}}$ \\
\hline & $40^{\circ} \mathrm{C}$ & $91.4 \pm 0.50^{\mathrm{a}}$ & $84.3 \pm 2.22^{\mathrm{a}}$ & $65.5 \pm 0.76^{\mathrm{b}}$ & $208 \pm 1.85^{\mathrm{b}}$ \\
& $50^{\circ} \mathrm{C}$ & $47.8 \pm 1.90^{\mathrm{b}}$ & $87.2 \pm 2.82^{\mathrm{a}}$ & $8.7 \pm 5.77^{\mathrm{d}}$ & $174 \pm 1.32^{\mathrm{d}}$ \\
\hline
\end{tabular}

DPPH-RSA, DPPH radical scavenging activity; SOD, superoxide dismutase activity; ABTS-RSA, ABTS radical scavenging activity; TPC, total phenolic contents.

${ }^{1)}$ The extracts from flowers were then dissolved in $95 \%$ ethanol in a concentration of $300 \mu \mathrm{g} / \mathrm{mL}$ for experiments except for SOD activity determination, where the concentration was $100 \mu \mathrm{g} / \mathrm{mL}$.

${ }^{2)}$ All values are mean $\pm \mathrm{SD}$ of triplicate determinations.

${ }^{3)}$ Different letters within a column indicate significant difference $(\mathrm{p} \leq 0.01), \mathrm{n}=3$. 
$85 \%$, respectively. TPC of the extract at $40^{\circ} \mathrm{C}$ and $60^{\circ} \mathrm{C}$ HAD condition were 202 and $234 \mu \mathrm{M}$ GAE, respectively. On the other hand, increasing temperature in FID condition decreased the antioxidant activities of the extracts.

Phenolic compounds are known to act as antioxidants not only because they are able to donate hydrogen or electrons, but also stable radical intermediates, which prevent oxidation of various food ingredients, particularly fatty acids and oils (25). Our previous studies showed that simple heat treatment of defatted sesame meal and citrus peel were effective in converting methanol insoluble phenolic compounds to methanol soluble forms $(26,27)$. Far-infrared heating could also cleave covalently bound phenolic compounds from rice hull, while simple heat could not. In the case of Chrysanthemi Flos flower, simple heating (HAD method) increased antioxidant activities with increasing temperature within range of $40 \sim 60^{\circ} \mathrm{C}$, however, far-infrared heating (FID method) showed the reverse effects in same temperature range. There are many kinds of phenolics in Chrysanthemi Flos flower, and the results indicate that phenolic compounds of the flower should present in many different bound forms. Therefore the effective processing steps for increasing antioxidant activities from different plant species may not be the same.

\section{Luteolin content}

Luteolin is one of key bioactive compounds of Chrysanthemi Flos flower, and plays an important role in anti-inflamation activity. The effect of drying condition on the luteolin content was determined. The luteolin content of the flower extracts was affected by both drying temperature and drying time (Table 3 ). Increasing temperature from $40^{\circ} \mathrm{C}$ to $50^{\circ} \mathrm{C}$ in $\mathrm{HAD}$ method increased the luteolin content from $103 \mu \mathrm{g} / \mathrm{mL}$ to $119 \mu \mathrm{g} /$ $\mathrm{mL}$, but at $60^{\circ} \mathrm{C}$ decreased to $95 \mu \mathrm{g} / \mathrm{mL}$. However, the effect of FID method on the content of luteolin was the exact opposite of the result of HAD method. In other words, the content decreased from $99 \mu \mathrm{g} / \mathrm{mL}$ to $85 \mu \mathrm{g} /$ $\mathrm{mL}$ according as the drying temperature of far-infrared
Table 3. Effect of hot-air drying (HAD) or far-infrared drying (FID) on the luteolin content of the Chrysanthemi Flos flower extracts

\begin{tabular}{ccc}
\hline \multicolumn{2}{c}{ Drying conditions } & Luteolin content $(\mu \mathrm{g} / \mathrm{mL})$ \\
\hline \multirow{4}{*}{ HAD } & $40^{\circ} \mathrm{C}$ & $103 \pm 0.7^{1) \mathrm{d} 2)}$ \\
& $50^{\circ} \mathrm{C}$ & $119 \pm 0.7^{\mathrm{b}}$ \\
& $60^{\circ} \mathrm{C}$ & $95 \pm 0.9^{\mathrm{e}}$ \\
\hline \multirow{3}{*}{ FID } & $40^{\circ} \mathrm{C}$ & $99 \pm 0.1^{\mathrm{c}}$ \\
& $50^{\circ} \mathrm{C}$ & $85 \pm 1.7^{\mathrm{f}}$ \\
& $60^{\circ} \mathrm{C}$ & $139 \pm 1.0^{\mathrm{a}}$
\end{tabular}

${ }^{1)}$ All values are mean $\pm \mathrm{SD}$ of triplicate determinations.

${ }^{2)}$ Different letters within a column indicate significant difference $(\mathrm{p} \leq 0.01), \mathrm{n}=3$.

radiation increased from $40^{\circ} \mathrm{C}$ to $50^{\circ} \mathrm{C}$, but increased at $60^{\circ} \mathrm{C}$ to $139 \mu \mathrm{g} / \mathrm{mL}$.

\section{Volatile compounds}

The detection and analysis of volatile compounds from the flower extracts of Chrysanthemi Flos was conducted by GC and GC/MS using SPME (Fig. 1). Thirteen volatile compounds were detected and used to observe the effect of drying conditions on the volatile compound. They were $\alpha$-pinene, camphene, $\beta$-myrcene, 1,8-cineole, 1,3,3-trimethylcyclohex-1-ene-4-carboxaldehyde, camphor, $\beta$-elemene, $\beta$-caryophyllene, $\beta$-farnesene, borneol, germacrene $\mathrm{D}, \alpha$-farnesene, $\beta$-sesquiphellandrene, which are known to have an antimicrobial activity or anticancer activity $(16,18-20)$. The contents of thirteen volatile compounds were calculated from the peak area of GC chromatogram, and the total content of the volatile compounds was the greatest $(100 \%)$ at $50^{\circ} \mathrm{C}$ HAD method and $40^{\circ} \mathrm{C}$ FID method (Table 4). Among thirteen compounds, camphor was the main volatile components $(31 \%)$ at $50^{\circ} \mathrm{C}$. $\beta$-Caryophyllene having an anti-fungal and antimutagen effect was also the greatest at $50^{\circ} \mathrm{C}$ as $4.4 \%(28,29)$. By increasing the drying temperature in HAD method, the total content of volatile compounds did not show a set pattern, that is, the content increased from $40^{\circ} \mathrm{C}$ to $50^{\circ} \mathrm{C}$ and then decreased from $50^{\circ} \mathrm{C}$ to $60^{\circ} \mathrm{C}$. On the contrary, as the drying temperature in-

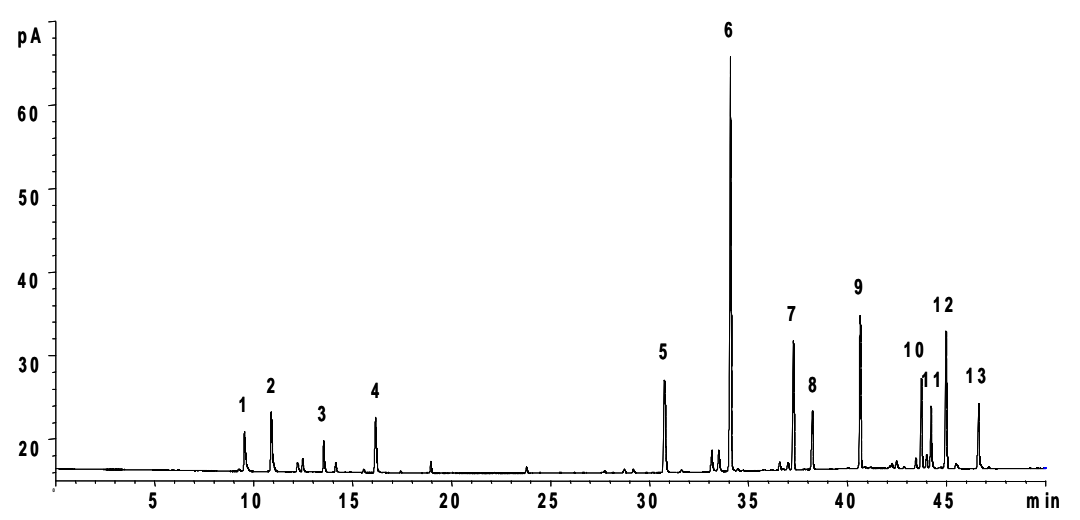

Fig. 1. Typical gas chromatography of the extract of Chrysanthemi Flos flowers which were dried with hot-air at $50^{\circ} \mathrm{C}$. Peak: $1, \alpha$ -pinene; 2, camphene; 3 , $\beta$-myrcene; $4,1,8$ cineole; 5, 1,3,3-trimethylcyclohex-1-ene-4carboxaldehyde; 6 , camphor; $7, \beta$-elemene; 8 , $\beta$-caryophyllene; $9, \beta$-farnesene; 10 , borneol; 11 , germacrene $\mathrm{D} ; 12, \alpha$-farnesene; $13, \beta$ -sesquiphellandrene. 
Table 4. Effect of hot-air drying (HAD) or far-infrared drying (FID) methods on volatile compounds of the Chrysanthemi Flos flower extracts

\begin{tabular}{|c|c|c|c|c|c|c|}
\hline & \multicolumn{6}{|c|}{ Peak area $(\%)$} \\
\hline & \multicolumn{3}{|c|}{ HAD } & \multicolumn{3}{|c|}{ FID } \\
\hline & $40^{\circ} \mathrm{C}$ & $50^{\circ} \mathrm{C}$ & $60^{\circ} \mathrm{C}$ & $40^{\circ} \mathrm{C}$ & $50^{\circ} \mathrm{C}$ & $60^{\circ} \mathrm{C}$ \\
\hline$\alpha$-Pinene & $2.7 \pm 0.06^{1) \mathrm{c} 2)}$ & $3.1 \pm 0.06^{\mathrm{b}}$ & $2.8 \pm 0.18^{\mathrm{c}}$ & $3.5 \pm 0.05^{\mathrm{a}}$ & $2.5 \pm 0.00^{\mathrm{c}}$ & $1.8 \pm 0.15^{\mathrm{d}}$ \\
\hline Camphene & $3.7 \pm 0.04^{\mathrm{b}}$ & $4.9 \pm 0.06^{\mathrm{a}}$ & $2.7 \pm 0.76^{\mathrm{cd}}$ & $3.4 \pm 0.03^{\mathrm{bc}}$ & $2.4 \pm 0.02^{\mathrm{d}}$ & $1.5 \pm 0.11^{\mathrm{e}}$ \\
\hline$\beta$-Myrcene & $2.3 \pm 0.07^{\mathrm{a}}$ & $1.9 \pm 0.01^{\mathrm{c}}$ & $1.8 \pm 0.08^{\mathrm{c}}$ & $2.1 \pm 0.03^{\mathrm{b}}$ & $1.6 \pm 0.02^{\mathrm{d}}$ & $1.1 \pm 0.09^{\mathrm{e}}$ \\
\hline 1,8 -Cineole & $1.9 \pm 0.06^{\mathrm{c}}$ & $4.3 \pm 0.04^{\mathrm{a}}$ & $2.3 \pm 0.10^{\mathrm{b}}$ & $2.5 \pm 0.03^{\mathrm{b}}$ & $2.3 \pm 0.03^{\mathrm{b}}$ & $1.5 \pm 0.07^{\mathrm{d}}$ \\
\hline $\begin{array}{l}\text { 1,3,3-Trimethylcyclohex-1-ene-4- } \\
\text { carboxaldehyde }\end{array}$ & $4.5 \pm 0.25^{\mathrm{e}}$ & $7.3 \pm 0.15^{\mathrm{c}}$ & $10.0 \pm 0.27^{\mathrm{a}}$ & $9.3 \pm 0.17^{\mathrm{b}}$ & $7.1 \pm 0.10^{c}$ & $5.9 \pm 0.21^{\mathrm{d}}$ \\
\hline Camphor & $29.8 \pm 0.39^{b}$ & $31.0 \pm 0.38^{\mathrm{a}}$ & $16.9 \pm 0.48^{\mathrm{d}}$ & $18.1 \pm 0.15^{\mathrm{c}}$ & $18.8 \pm 0.01^{\mathrm{c}}$ & $13.0 \pm 0.42^{\mathrm{e}}$ \\
\hline$\beta$-Elemene & $5.9 \pm 0.35^{\mathrm{d}}$ & $9.5 \pm 0.40^{\mathrm{a}}$ & $6.7 \pm 0.15^{\mathrm{c}}$ & $7.9 \pm 0.11^{\mathrm{b}}$ & $7.3 \pm 0.38^{\mathrm{bc}}$ & $7.4 \pm 0.21^{\mathrm{bc}}$ \\
\hline$\beta$-Caryophyllene & $2.5 \pm 0.12^{\mathrm{e}}$ & $4.4 \pm 0.07^{\mathrm{a}}$ & $3.3 \pm 0.01^{\mathrm{c}}$ & $3.7 \pm 0.02^{\mathrm{b}}$ & $3.4 \pm 0.11^{\mathrm{c}}$ & $3.1 \pm 0.02^{\mathrm{d}}$ \\
\hline$\beta$-Farnesene & $6.5 \pm 0.32^{\mathrm{c}}$ & $9.9 \pm 0.10^{\mathrm{b}}$ & $9.3 \pm 0.11^{\mathrm{b}}$ & $11.1 \pm 0.11^{\mathrm{a}}$ & $9.7+0.49^{b}$ & $9.6+0.22^{\mathrm{b}}$ \\
\hline Borneol & $3.0 \pm 0.25^{\mathrm{c}}$ & $5.6 \pm 0.05^{\mathrm{b}}$ & $5.8 \pm 0.05^{\mathrm{ab}}$ & $6.2 \pm 0.05^{\mathrm{a}}$ & $6.0 \pm 0.32^{\mathrm{ab}}$ & $5.9 \pm 0.13^{\mathrm{ab}}$ \\
\hline Germacrene D & $3.6 \pm 0.30^{\mathrm{c}}$ & $4.4 \pm 0.08^{\mathrm{b}}$ & $6.7 \pm 0.07^{\mathrm{a}}$ & $6.7 \pm 0.15^{\mathrm{a}}$ & $6.9 \pm 0.27^{\mathrm{a}}$ & $6.7 \pm 0.13^{\mathrm{a}}$ \\
\hline$\alpha$-Farnesene & $7.1 \pm 0.50^{\mathrm{c}}$ & $8.8 \pm 0.17^{\mathrm{b}}$ & $10.8 \pm 0.11^{\mathrm{a}}$ & $10.4 \pm 0.15^{\mathrm{a}}$ & $10.7 \pm 0.51^{\mathrm{a}}$ & $10.5 \pm 0.35^{\mathrm{a}}$ \\
\hline$\beta$-Sesquiphellandrene & $5.7 \pm 0.35^{\mathrm{c}}$ & $4.9 \pm 0.10^{\mathrm{d}}$ & $7.7 \pm 0.06^{\mathrm{b}}$ & $9.4 \pm 0.06^{\mathrm{a}}$ & $8.2 \pm 0.41^{\mathrm{b}}$ & $9.2 \pm 0.30^{\mathrm{a}}$ \\
\hline Total & $79.2 \pm 2.39^{d}$ & $100.0 \pm 1.00^{\mathrm{a}}$ & $86.8 \pm 1.16^{\mathrm{c}}$ & $94.3 \pm 0.61^{b}$ & $86.9 \pm 2.52^{\mathrm{c}}$ & $77.2 \pm 0.76^{\mathrm{e}}$ \\
\hline
\end{tabular}

${ }^{1)}$ All values are mean $\pm \mathrm{SD}$ of triplicate determinations.

${ }^{2)}$ Different letters within a row indicate significant difference $(\mathrm{p} \leq 0.01), \mathrm{n}=3$.

creased in FID method, the total content of volatile compounds decreased significantly $(\mathrm{p}<0.01)$. The content of the extracts at $40^{\circ} \mathrm{C}$ FID method was $94.3 \%$, while at $60^{\circ} \mathrm{C}$ FID method was $77.2 \%$. Far-infrared rays are defined as electromagnetic waves having a wavelength of longer than $4 \mu \mathrm{m}$ but shorter than microwaves $(\lambda>0.1$ $\mathrm{cm})$. FIR rays transfer heat to the center of materials evenly, while simple hot air heats from the surface to center of materials. Therefore, FID method might significantly affect the content of volatile compared to the HAD method.

In conclusion, drying conditions of Chrysanthemi Flos flower significantly affect the antioxidant activities, luteolin, and volatile compounds of $95 \%$ ethanol extract of flowers. For example, increasing temperature in HAD conditions increased the antioxidant activities, while increasing temperature in FID conditions decreased the antioxidant activities of the extracts. Luteolin was present in the highest content at $60^{\circ} \mathrm{C}$ FID flowers, and higher amount of the volatiles were found at $50^{\circ} \mathrm{C}$ HAD and $40^{\circ} \mathrm{C}$ FID. These results support that the drying condition should be primarily considered when the Chrysanthemi Flos flowers are dried for a medicinal resource.

\section{ACKNOWLEDGEMENT}

This study was supported by Kyungnam University Research Fund, 2008.

\section{REFERENCES}

1. Kim TJ. 1996. Korean Resources Plants. Seoul National
Univ. Press, Seoul, Korea.

2. Yan YC, Lou XE, Jiang HD. 1999. Experimental studies on the anti-oxidation effects of water extract from Chrysanthemum indicum. Zhong Guo Xian Dai Ying Yong Yao Xue Za Zhi 16: 16-18.

3. Cheng W, Li J, You T, Hu C. 2005. Anti-inflammatory and immunomodulatory activities of the extracts from the inflorescence of Chrysanthemum indicum Linné. $J$ Ethnopharmacol 101: 334-337.

4. Chen ZN, Xu PJ. 1987. Structural determination of yejuhua lactone isolated from Chrysanthemum indicum L. Yao Xue Xue Bao 22: 67-69.

5. Yoshikawa M, Morkawa T, Murakami T, Toguchida I, Harima S, Matsuda H. 1999. Medicinal flowers. I. Aldose reductase inhibitors and three eudesmane-type sesquiterpenes, kikanols $\mathrm{A}, \mathrm{B}$, and $\mathrm{C}$, from the flowers of Chrysanthemum indicum L. Chem Pharm Bull 3: 340345.

6. Hong CU. 2002. Essential oil composition of Chrysanthemum boreal and Chrysanthemum indicum. J Korean Soc Agric Chem Biotechnol 45: 108-113.

7. Shin YJ, Jeon JR, Park GS. 2004. Physicochemical properties of Gamgug (Chrysanthemum indicum L.). J Korean Soc Food Sci Nutr 33: 146-151.

8. Bae KH, Kim YH, Min BS, Jung HJ. 1999. The quality evaluation of Chrysanthemi Flos. Kor J Pharmacog 30: 65-69.

9. Chien MK, Chen CH, Tseng KF. 1963. The constituents of yejuhua. The flower of Chrysanthemum indicum. II. The structure of yejuhua lactone. Yao Hsueh Hsueh Pao 10: $129-132$.

10. Chatterjee A, Saekar S, Saha SK. 1981. Acacetin 7-O-galactopyranose from Chrysanthemum indicum. Phytochemistry 20: $1760-1764$.

11. Ryu SY, Choi SU, Lee CO, Lee SH, Ahn JW, Zee OP. 1994. Antitumor activity of some phenolic compounds in plants. Arch Pharm Res 17: 42-44.

12. Simoes CM, Schenkel EP, Bauer L, Langeloh A. 1988. Pharmacological investigations on achyrocline satureioides. 
J Ethnopharmacol 22: 281-293.

13. Kazuyasu S, Kazuki K, Hitoshi A, Genichi D. 1995. Luteolin: a strong antimutagen against dietary carcinogen, T-P-2, in peppermint, sage, and thyme. J Agric Food Chem 43: 410-414.

14. Kris-Etherton PM, Lefevre M, Beecher GR, Gross MD, Keen CL, Etherton TD. 2004. Bioactive compound in nutrition and health-research methodologies for establishing biological function: the antioxidant and anti-inflammatory effects of flavonoids on atherosclerosis. Annu Rev Nutr 24: 511-538.

15. Shi RX, Ong CN, Shen HM. 2004. Luteolin sensitizes tumor necrosis factor- $\alpha$-induced apoptosis in human tumor cells. Nature 23: 7712-7721.

16. Mourey A, Canillac N. 2002. Anti-Listeria monocytogenes activity of essential oils components of conifers. Food Control 13: 289-292.

17. Zhu S, Yang Y, Yu H, Ying Y, Zou G. 2005. Chemical composition and antimicrobial activity of the essential oils of Chrysanthemum indicum L. J Ethnopharmacol 96: 151-158.

18. Braca A, Siciliano T, D'Arrigo M, Germanò MP. 2007. Chemical composition and antimicrobial activity of Momordica charantia seed essential oil. Fitoterapia 79: 123-125.

19. Vivek KB, Atiqur R, Kang SC. 2007. Chemical composition and anti-fungal properties of the essential oil and crude extracts of Metasequoia glyptostroboides Miki ex Hu. Ind Crop Prod 26: 28-35.

20. Legault J, Pichette A. 2007. Potentiating effect of beta-caryophyllene on anticancer activity of alphahumulene, isocaryophyllene and paclitaxel. J Pharm Pharmacol 59: 1643-1647.
21. Lee SC, Kim JH, Jeong SM, Kim DR, Ha JU, Nam KC, Ahn DU. 2003. Effect of far-infrared radiation on the antioxidant activity of rice hulls. J Agric Food Chem 51: 4400-4403.

22. Muller HE. 1985. Detection of hydrogen peroxide produced by microorganism on ABTS-peroxidase medium. Zentralbl Bakteriol Mikrobiol Hyg 259: 151-158.

23. Gutfinger T. 1981. Polyphenol in olive oils. J Am Oil Chem Soc 58: 996-998.

24. Kong LD, Cai Y, Huang WW, Cheng CHK, Tan RX. 2000. Inhibition of xanthine oxidase by some Chinese medicinal plants used to treat gout. J Ethnopharmacol 73: 199-207.

25. Cuvelier ME, Richard H, Berset C. 1992. Comparison of the antioxidant activity of some acid phenols: structure-activity relationship. Biosci Biotechnol Biochem 56: 324 325 .

26. Jeong SM, Kim SY, Kim DR, Nam KC, Ahn DU, Lee SC. 2004b. Effect of seed roasting conditions on the antioxidant activity of defatted sesame meal extracts. J Food Sci 69: 377-381.

27. Jeong SM, Kim SY, Kim DR, Jo SC, Nam KC, Ahn DU, Lee SC. 2004a. Effect of heat treatment on antioxidant activity of citrus peels. J Agric Food Chem 52: 3389-3393.

28. Farrell KT. 1985. Spices, condiments, and seasonings. In Spices and Culinay Herbs. Avl Publishing, New York, NY, USA.

29. Kim JO, Kim YS, Lee JH, Kim MN, Rhee SH, Moon SH, Park KY. 1992. Antimutagenic effect of the major volatile compounds identified from mugwort (Artemisia asatica Nakai) leaves. J Korean Soc Food Sci Nutr 21: 308-309.

(Received August 31, 2009; Accepted September 14, 2009) 